\title{
Análise sobre a estrutura urbana nos planos urbanísticos recentes de São Paulo (1968 - 2016)
}

\author{
Thoughts on the urban structure of the recent urban \\ plans in São Paulo (1968-2016)
}

Sidney Piochi Bernardini [a] [D, Priscila Regina Sato [a] [D

[a] Universidade Estadual de Campinas, Departamento de Arquitetura e Construção, Faculdade de Engenharia Civil, Arquitetura e Urbanismo, Campinas, SP, Brasil

Como citar: Bernardini, S. P., \& Sato, P. R. (2021). Análise sobre a estrutura urbana nos planos urbanísticos recentes de São Paulo. urbe. Revista Brasileira de Gestão Urbana, v. 13, e20200195. https://doi.org/10.1590/2175-

3369.013.e20200195

\section{Resumo}

0 artigo tem como objetivo apresentar uma análise transversal das propostas de estrutura urbana estabelecidas nos planos formulados para o município de São Paulo entre 1968, com o Plano Urbanístico Básico (PUB), e 2016, com a instituição da Lei de Uso e Ocupação do Solo mais recente. O PUB foi considerado como ponto de partida por conter, na sua concepção, aspectos relevantes do pensamento sobre planejamento urbano paulistano e a definição clara de uma estrutura urbana futura. A pesquisa buscou fazer esta análise comparativa considerando os conteúdos gráficos utilizados nos planos selecionados. A semiologia gráfica foi o método utilizado para construir esquemas conceituais que padronizassem as propostas, buscando trazer maior precisão quanto ao posicionamento conceitual estabelecido, demonstrando, por um lado, como os modelos teóricos, nos momentos em que os planos foram elaborados, dialogaram com as problemáticas socioeconômicas e, de outro, como foram recorrentes ao longo do tempo.

Palavras-chave: São Paulo. Planos diretores. Estrutura urbana. Uso e ocupação do solo. Planejamento urbano e regional.

\section{Abstract}

This article aims to present a cross-sectional analysis of the urban structure proposals established in the plans formulated for the municipality of São Paulo between 1968, with the publication of the Basic Urban Plan (PUB), and 2016, with the establishment of the last Land Use and Occupation Law. PUB was considered as a starting point because it contains, in its conception, relevant aspects of thinking about urban planning in São Paulo and the clear definition of a future urban structure. The research sought to make this comparative analysis considering the graphic contents used in the selected plans. Graphical semiology was

SPB é arquiteto e urbanista, doutor em Arquitetura e Urbanismo, e-mail: spiochi@unicamp.br

PRS é arquiteta e urbanista, mestre em Arquitetura e Urbanismo, e-mail: prirsato@gmail.com 
the method used to build conceptual schemes that standardize the proposals, seeking to bring greater precision regarding the established conceptual positioning, demonstrating, on the one hand, how the theoretical models, at the moments when the plans were elaborated, dialogued with the problems socioeconomic conditions, and on the other, as they have been recurring over time.

Keywords: São Paulo. Master plans. Urban structure. Land use and occupation. Urban and regional planning.

\section{Introdução}

Diante da complexidade e da amplitude relacionada à história do planejamento urbano em São Paulo, torna-se oportuno questionar se é possível pensar uma narrativa que consiga explicar como se construiu o pensamento sobre as políticas de estruturação urbana para a cidade. Não são poucos os trabalhos que buscaram fazer essa trajetória, sob os mais diversos enfoques e métodos historiográficos. É possível pensar essa história a partir de fragmentos, observando-se cada um dos planos e propostas realizados, considerando cada qual contendo uma concepção singular e exclusiva do seu tempo, mas também é possível pensar uma estruturação do pensamento que se deu de forma contínua e processual, em diálogo constante com a rápida urbanização que varreu toda a "aglomeração urbana" paulistana já a partir da década de 1940 (Meyer et al., 2004). Os já muito conhecidos planos emblemáticos para São Paulo, como os de Prestes Maia, Robert Moses e SAGMACS além de outros, entre 1930 e 1960 (Leme, 1999; Anelli, 2007), despontaram um horizonte de ideias que puderam ser sistematizadas, evidenciando aspectos importantes do urbanismo paulistano. Pode-se perguntar em que medida estas propostas tiveram um efeito concreto sobre as transformações urbanas pelas quais passou a cidade a posteriori, considerando as tantas intervenções realizadas. Mas também é possível perguntar como este pensamento se cristalizou ou foi se desenvolvendo pari passu a estas transformações. Em que medida esta herança do pensamento está presente nos planos e propostas mais atuais? A estrutura urbana de São Paulo, que foi se consolidando ao longo das décadas, determinou uma forma única de pensar sobre ela ou houve desdobramentos deste pensamento?

Planos e propostas estão, com frequência, associados aos autores e agentes: engenheiros, urbanistas ou outros profissionais que lidam com a prática do planejamento. As interpretações, neste sentido, se fazem passar muitas vezes por aspectos biográficos ou de suas trajetórias profissionais relacionados às organizações às quais estes profissionais pertenceram. Por isso estão assim vinculados: plano Prestes Maia, plano Moses, etc. Mesmo relevante, a opção pelas narrativas que buscam expor a forma do pensamento condensado pelos profissionais que atuaram ou atuam sobre a cidade pode, muitas vezes, ofuscar um ideário que se estruturou ao longo do tempo, estabelecendo-se nas organizações sociais, institucionais e na própria sociedade, assim como afirma Cerasoli (2014) sobre a natureza transdisciplinar do campo dos estudos urbanos. Nesta perspectiva, torna-se desafiador conceber uma narrativa que busque observar a construção de um pensamento sobre o planejamento urbano decorrente de uma teia, uma rede interligada de ideias e significados potencializados pelas problemáticas, demandas, desafios, impasses e dilemas. Assim, o planejamento urbano observado como uma relação entre processos e resultados (Friedmann, 2011) poderia orientar a abordagem sobre a construção de um pensamento.

Este artigo apresenta uma análise transversal das propostas de estrutura urbana, assim como, o percurso do pensamento estabelecido pelo conjunto de planos elaborados para o município de São Paulo e sua região entre 1968, com a publicação do Plano Urbanístico Básico (PUB), e 2016, com a instituição da Lei de Parcelamento, Uso e Ocupação do Solo atual, conforme Figura 1. Tomando os planos e propostas como principais elementos de análise, a investigação procurou observar como estes documentos organizaram suas recomendações relacionadas exclusivamente à estrutura urbana da metrópole paulistana. Ao considerar os dilemas presentes no crescimento do tecido urbano de forma 
rápida e extensiva, combinada a um aumento explosivo de sua população que foi acentuando os movimentos pendulares na relação entre trabalho e moradia, toma-se como pressuposto que uma solução para a estruturação urbana da metrópole foi um constante desafio no âmbito dos planos desenvolvidos neste período. Assim é que, ao isolar o componente da estrutura urbana em todos os planos observados, procurou-se iluminar uma trajetória do pensamento que foi se desenvolvendo neste âmbito.

As variadas vertentes de interpretação do conceito de estrutura urbana combinam, em geral, elementos singulares das relações estabelecidas pelas localizações do espaço urbano. Para Silva (2013) e Kneib (2014), a estrutura urbana se conforma a partir da relação entre uso do solo, produto das atividades sociais, e o sistema de transportes, articulador que assegura as necessidades de interrelações entre as diversas atividades. Esta interpretação se complementa com a de Rodrigue (2006), que a compreende como a combinação de dois elementos compostos: os links e o nós, sendo os nós as centralidades de maior acessibilidade e/ou concentração econômica, interligadas pelos "links" que são as infraestruturas responsáveis pelos fluxos entre eles. Todavia, posicionamentos simplificadores podem obscurecer as dinâmicas de transformação da estrutura urbana. É necessário compreender que o valor de uso resultante das forças produtivas do trabalho social e das aglomerações consiste basicamente na estrutura das localizações. A formulação trazida por Villaça (2017) potencializa este pressuposto. 0 valor de uso se faz a partir do "relacionamento" entre as localizações, na constante agregação de valor inerente às transformações que se realizam ao longo do tempo. Assim é que, para Villaça, a estrutura do espaço urbano depende das transformações destas localizações: seus atributos, valores, preços, usos e acessibilidades.

A hipótese aqui lançada é de que houve a permanência de um pensamento sobre a estrutura urbana que se estabeleceu nos planos e propostas para a metrópole paulistana a partir do final dos anos 1960 até a última proposta formulada (Lei de parcelamento, uso e ocupação do solo de 2016), vinculada a uma certa "inércia" estabelecida pela sua consolidação e que, embora tenha se modificado ao longo das últimas décadas, determinou uma continuidade na busca de uma solução mais racional para as deseconomias geradas no âmbito das aglomerações, de suas altas densidades populacionais e do processo de periferização. Neste sentido, supõe-se que, embora as transformações sejam significativas do ponto de vista da produção de localizações no espaço urbano, a base estrutural que dá suporte a elas se manteve em constante diálogo com as intervenções que se realizaram, resultantes ou não dos planos. Nesta dialética, teria havido uma busca incessante por consolidar esta estrutura, preconizando-se tornála mais ordenada e eficaz, a partir do sistema estrutural de transportes, regiões de adensamento, polos de centralidade, entre outros aspectos. Ainda que o jogo de forças políticas seja inerente aos mecanismos que se fizeram presentes neste processo, este trabalho traça um horizonte mais estreito entre a formulação de um ideário planificador, pontuado pela atuação ampla de agentes sociais e a estrutura urbana, como uma matriz sólida, mas também em constante modificação.

Para enfrentar esta tarefa foram selecionados os principais planos urbanísticos realizados no período da pesquisa, incluindo neste rol a primeira lei de zoneamento de 1972 e as duas leis de parcelamento, uso e ocupação do solo instituídas já no final do período, entre 2004 e 2016. Considerouse que as leis de zoneamento, por serem instrumentos autoaplicáveis, são menos refratárias a mudanças substanciais que, em geral, postulam resultados de conflituosos processos de negociação com os agentes do mercado e concorrem para a permanência de certas liberalidades e menores restrições urbanísticas. Assim, serviram como indicadores desta relação entre o pensamento e sua difícil ancoragem, o que ensejou uma análise paralela. Além destas leis, também foram tomados como referência, embora não analisados aqui, os Planos Integrados de Transporte Urbano - PITU 2020, desenvolvidos pelo governo estadual também neste período. A amplitude e abrangência regional destas propostas tornariam a análise demasiadamente complexa, razão pela qual optou-se por excluí-los deste trabalho. Cabe ressaltar, entretanto, que embora tenham sido selecionados os planos exclusivamente contratados ou 
elaborados pela administração municipal, o PUB foi elaborado para aglomeração urbana (na escala regional, abrangendo os municípios que viriam a compor a região metropolitana), o que nos obrigou a também adotar o Plano Metropolitano de Desenvolvimento Integrado, que foi um desdobramento direto dele, mas elaborado pelo governo estadual, já no âmbito das suas políticas metropolitanas. Todos os planos e propostas realizados pelo município foram incluídos na análise, independentemente de terem sido ou não aprovados ou utilizados posteriormente, com exceção do Plano Diretor de 1971, por não possuir mapa. Além de uma leitura completa dos documentos, a pesquisa buscou se fixar na análise da cartografia neles presente.

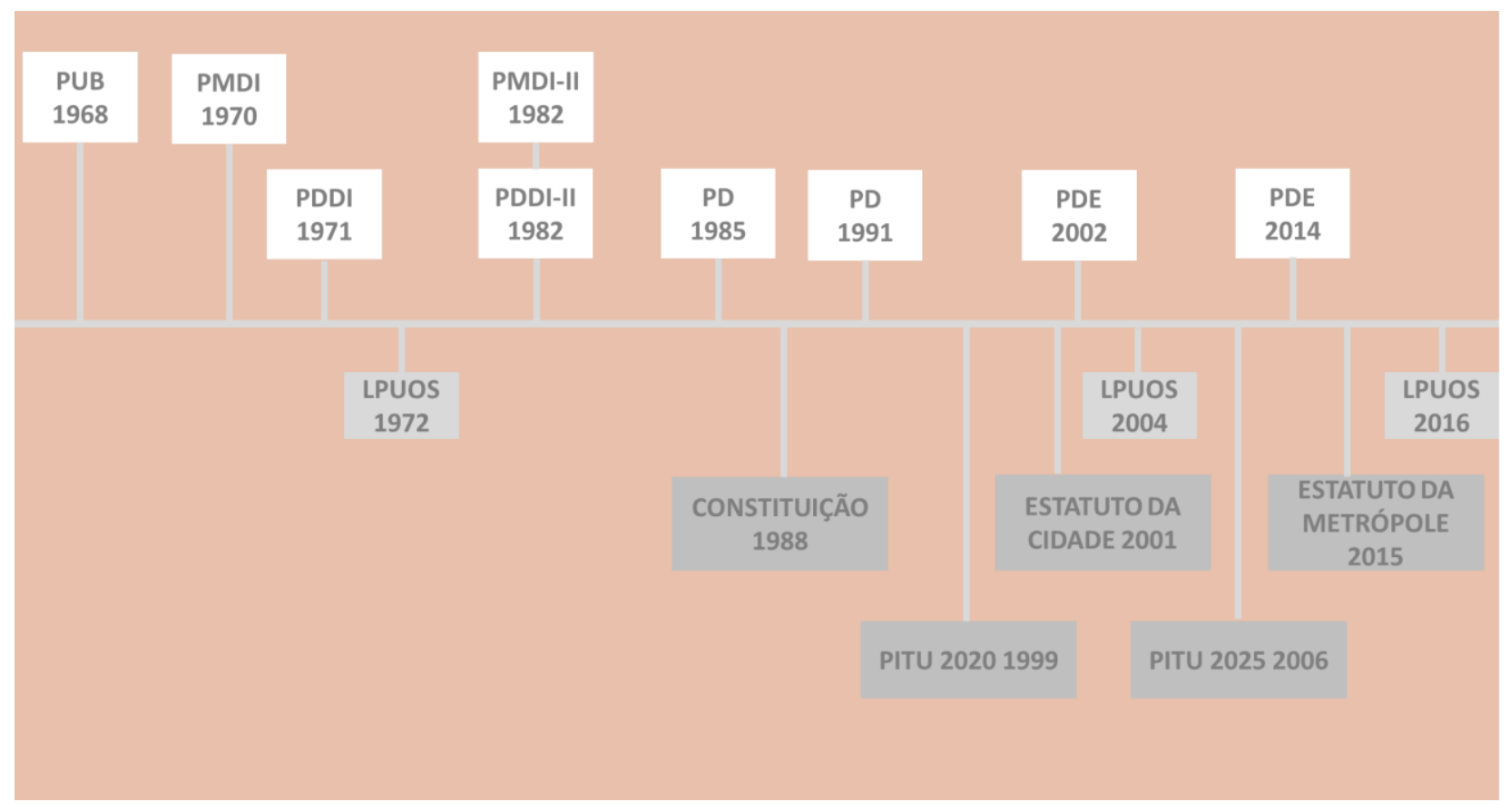

Figura 1 - Linha do tempo dos planos urbanísticos para São Paulo. Fonte: elaboração dos autores.

\section{Método: a coremática como ferramenta de análise cartográfica}

A simples leitura de extensos diagnósticos, textos e leis, assim como dos próprios mapas anexos dos planos não é suficiente, muitas vezes, para uma compreensão clara e precisa da essência propositiva ali contida. A síntese projetiva que evoca a condição de existir dos planos - suas estruturas espaciais, mesmo constante das suas peças escritas e gráficas, podem não ser visualmente compreendidas. Além disso, para situações em que se pretende comparar diversos documentos, de tempos diferentes, as várias técnicas de representações utilizadas no decorrer dos anos tornam ainda mais difícil lograr ter uma síntese propositiva com a devida exatidão, cuja análise pode ficar sujeita a erros de interpretações advindos da própria variação de elementos utilizados em cada uma das propostas. Assim é que o esforço de interpretação exige ferramentas de normalização das várias representações no tempo que também deem cabo de uma legibilidade das propostas estabelecidas, tornando a síntese projetiva visível para a leitura e posterior comparação. Para isso, foi necessário buscar uma técnica de visualização.

A ferramenta utilizada para tanto foi a coremática, derivada dos conhecimentos da semiologia gráfica. Jacques Bertin estruturou as suas diretrizes ainda na década de 1960 (Archela, 2001), buscando dar uma padronização na representação gráfica para a produção cartográfica. Além de dar parâmetros para uma padronização cartográfica, a semiologia gráfica possibilitou o desenvolvimento de outras abordagens e investigações nas relações entre os mapas e os "discursos" a eles subjacentes, como a modelagem urbana, verificada pela teoria da coremática de Roger Brunet (1986), que introduziu esta ferramenta para traduzir a estreita relação entre a organização espacial e a sociedade que a produz. 0 
método procura identificar graficamente os agentes produtores do espaço, vinculando-os a elementos essenciais da estrutura urbana: a malha, que representa o conjunto de divisões territoriais públicas ou privadas; a rede, que corresponde à infraestrutura de circulação de pessoas e mercadorias, assim como sua comunicação; a divisão do trabalho, que orienta os espaços do trabalho e da moradia.

Para representar as dinâmicas envolvidas entre estes "atores" e os diferentes espaços produzidos, Brunet (1986) sistematizou cinco efeitos destas estruturas espaciais: a gravitação que corresponde à relação de distâncias entre centro e periferia; o contato, que expressa a dinâmica de atração e repulsão entre os elementos; o tropismo, indicando direções e orientações de fluxos; a dinâmica territorial que apresenta movimentos de expansão e retração e, por fim, a hierarquia que ordena os níveis de estruturação do espaço. A aplicação da coremática na modelagem urbana no Brasil pode ser verificada pelos estudos de Théry (2012) e, com enfoque no município de São Paulo, pela pesquisa de Gonçalves (2012), visualizadas nas Figuras 2 e 3. No modelo de Théry (2012), o autor buscou demonstrar a competitividade entre as atividades industriais e de serviço, e indica em seu modelo final quatro áreas estratégicas de expansão destas atividades. Já no modelo de Gonçalves, o enfoque é dado para apresentar dinâmicas sociais e conflitos econômicos.
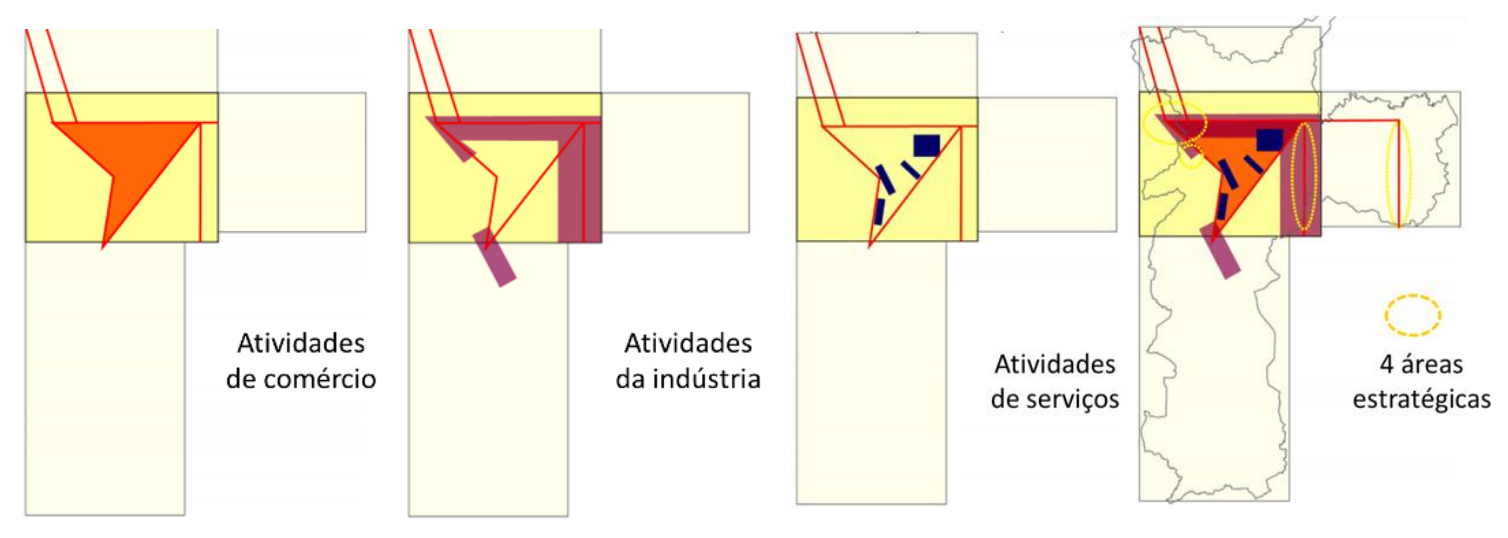

Figura 2 - Modelos coremáticos para o município de São Paulo. Fonte: Théry (2012).
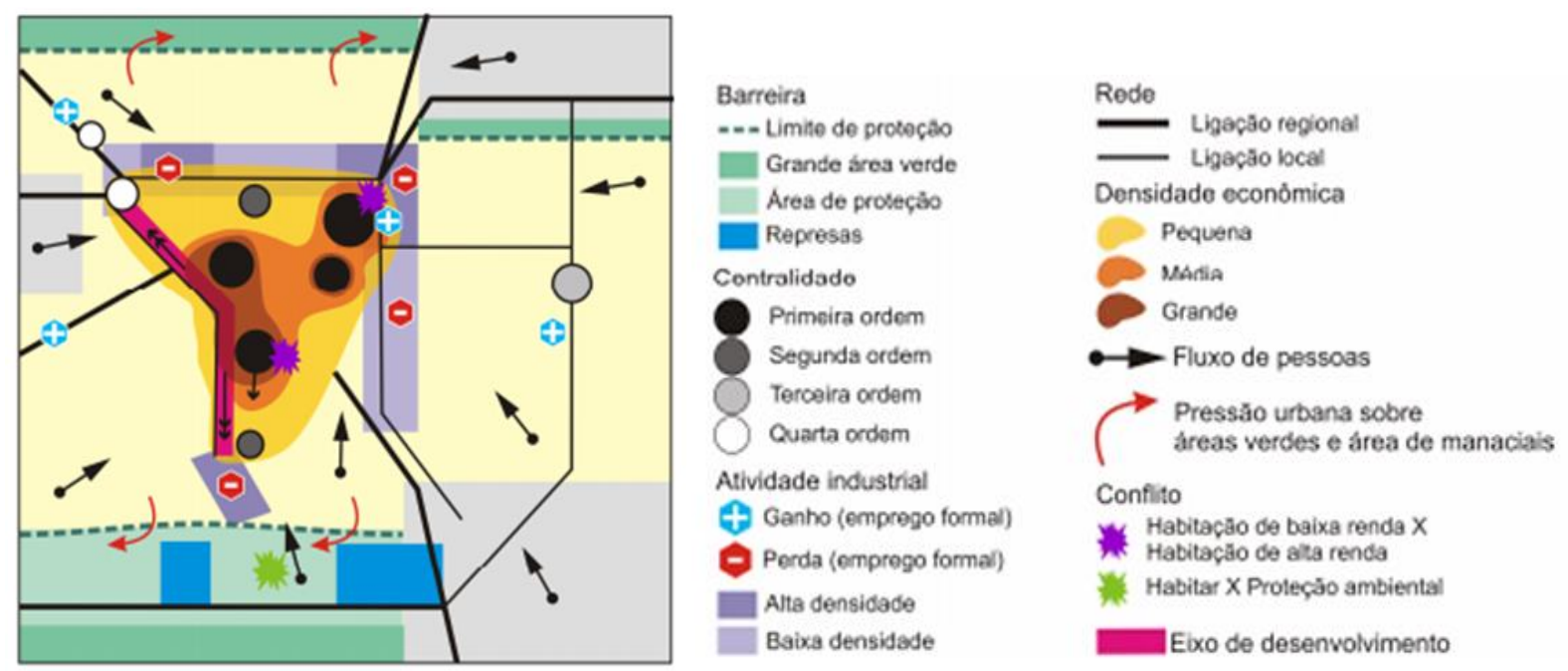

Figura 3 - Modelos coremáticos para o município de São Paulo. Fonte: Gonçalves (2012).

A partir do estabelecimento da principal ferramenta de normalização das propostas cartográficas, a pesquisa foi estruturada tomando-se os seguintes procedimentos (1) alinhavar as principais definições acerca da estrutura urbana proposta nos documentos, selecionando-se, dos textos, posteriormente, todos os trechos que dispunham sobre elas, em conformidade com a acepção conceitual estabelecida de antemão; (2) verificar como estas propostas estavam identificadas e representadas nos 
mapas anexos, estabelecendo uma organização dos elementos principais que deveriam ser considerados na sua conversão para a coremática; (3) elaborar os desenhos interpretativos de cada mapa selecionado nos documentos, utilizando-se para isso o software Photoshop, versão CC2018, com base na técnica da coremática acima descrita; (4) cruzar as informações contidas nos textos propositivos selecionados no item 1 com os elementos identificados e desenhados para uma calibragem conceitual entre o escrito e o desenhado, de forma a alinhar com mais precisão a relação entre as linguagens; (5) análise dos resultados, tomando-se, essencialmente, os desenhos resultantes para a observação de se a hipótese foi comprovada.

A construção dos esquemas gráficos partiu de uma base cartográfica desenvolvida contendo os elementos estáveis, que estariam presentes em todos eles (Figura 4). Cabe ressaltar que a base cartográfica considera a escala da Região Metropolitana de São Paulo, e não somente o município, pois considera as diferentes abrangências das propostas estudadas, bem como as dinâmicas territoriais metropolitanas. Além disso, durante o processo de construção dos esquemas algumas padronizações tiveram de ser adotadas devido aos diferentes modos de representação e dos termos e expressões utilizadas nas legendas, o que exigiu um esforço para a reunião de diferentes padrões de uso e ocupação do solo em categorias similares. Para aglutinar as categorias, foram sistematizadas as propostas utilizadas nos planos e sua correspondência aos níveis de ocupação e diversidade de uso do solo, conforme apresentado nos Quadros 1 e 2.

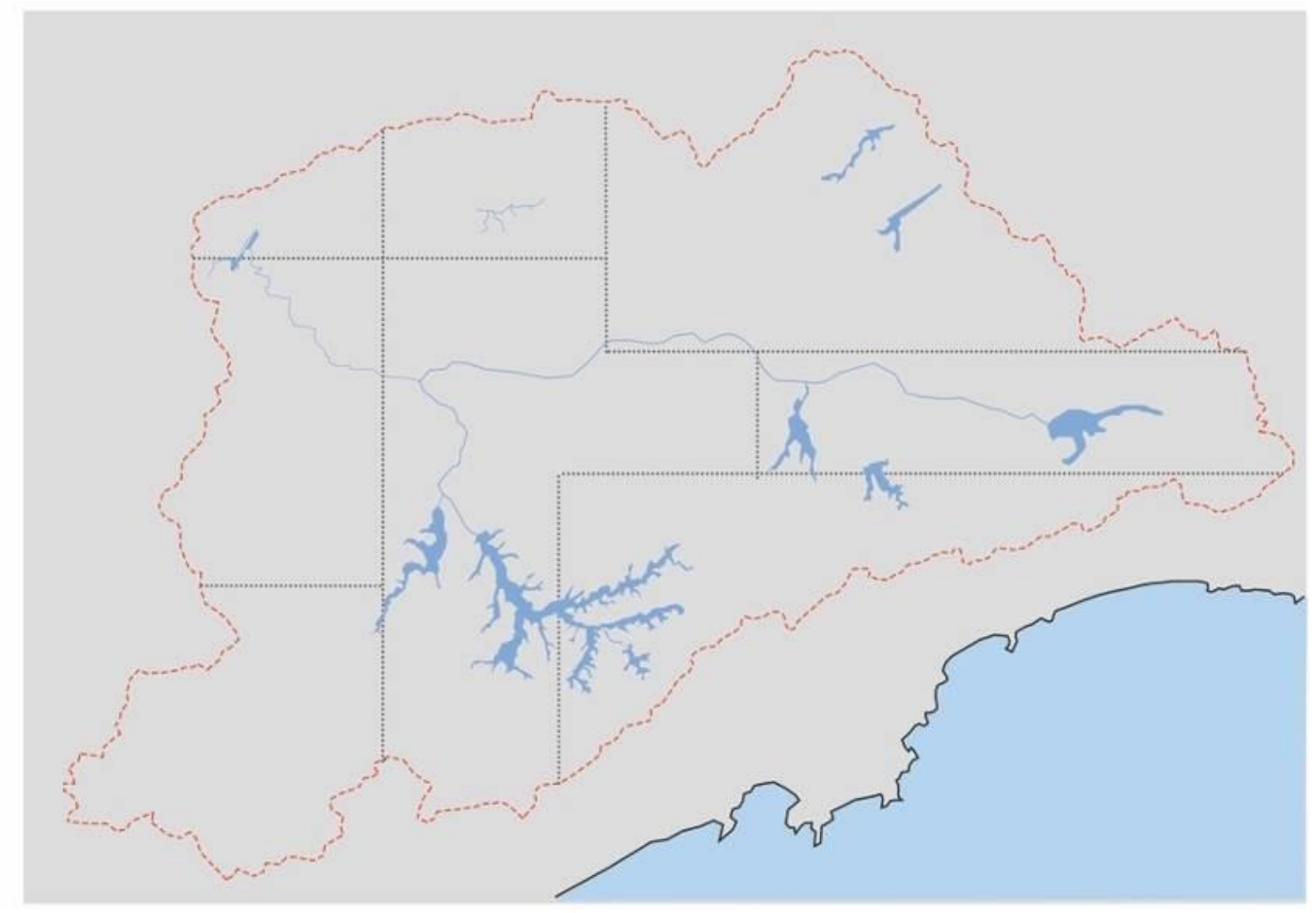

Figura 4 - Base gráfica dos esquemas conceituais - elementos estáveis. Fonte: elaborado pelos autores. 
Quadro 1 - Padronização e legenda das propostas dos planos

\begin{tabular}{|c|c|c|c|}
\hline & $\begin{array}{l}\text { Maior diversidade do uso do } \\
\text { solo e intensidade de } \\
\text { ocupação }\end{array}$ & $\begin{array}{l}\text { Média diversidade de uso do } \\
\text { solo e intensidade de } \\
\text { ocupação }\end{array}$ & $\begin{array}{l}\text { Baixa diversidade do uso e } \\
\text { intensidade de ocupação }\end{array}$ \\
\hline PUB & $\begin{array}{l}\text { Intenso desenvolvimento } \\
\text { urbano }\end{array}$ & & $\begin{array}{l}\text { Menor desenvolvimento } \\
\text { urbano }\end{array}$ \\
\hline PMDI & $\begin{array}{l}\text { Alta densidade e } \\
\text { concentração do comércio }\end{array}$ & $\begin{array}{l}\text { Média densidade } \\
\text { habitacional e concentração } \\
\text { de comércio }\end{array}$ & $\begin{array}{l}\text { Baixa densidade habitacional } \\
\text { e concentração de comércio }\end{array}$ \\
\hline PDDI & Centro metropolitano & $\begin{array}{l}\text { Áreas com concentração de } \\
\text { atividades terciárias }\end{array}$ & \\
\hline 1982 & & $\begin{array}{l}\text { Áreas especiais de expansão } \\
\text { das atividades terciárias }\end{array}$ & \\
\hline PD & $\begin{array}{l}\text { Estimular o uso e ocupação do } \\
\text { solo }\end{array}$ & $\begin{array}{l}\text { Controlar e intensificar o uso e } \\
\text { a ocupação do solo }\end{array}$ & $\begin{array}{l}\text { Controlar intensificação de uso } \\
\text { e ocupação do solo }\end{array}$ \\
\hline 1985 & & & $\begin{array}{l}\text { Zona horizontal a manter } \\
\text { padrão urbano }\end{array}$ \\
\hline $\begin{array}{l}\text { PD } \\
1991\end{array}$ & $\begin{array}{l}\text { Alto potencial de } \\
\text { adensamento }\end{array}$ & $\begin{array}{l}\text { Médio potencial de } \\
\text { adensamento }\end{array}$ & $\begin{array}{l}\text { Baixo potencial de } \\
\text { adensamento } \\
\text { Não adensável }\end{array}$ \\
\hline $\begin{array}{l}\text { PDE } \\
2002\end{array}$ & $\begin{array}{l}\text { Reestruturação e } \\
\text { requalificação }\end{array}$ & $\begin{array}{l}\text { Urbanização em } \\
\text { consolidação } \\
\text { Urbanização e qualificação }\end{array}$ & Urbanização consolidada \\
\hline $\begin{array}{l}\text { PDE } \\
2014\end{array}$ & Estruturação metropolitana & Qualificação e urbanização & $\begin{array}{l}\text { Urbanização consolidada } \\
\text { Redução da vulnerabilidade } \\
\text { ambiental }\end{array}$ \\
\hline
\end{tabular}

Fonte: elaborado pelos autores.

Quadro 2 - Padronização e legenda das Leis de zoneamento, parcelamento, uso e ocupação do solo

\begin{tabular}{|c|c|c|c|}
\hline & 1972 & 2004 & 2016 \\
\hline $\begin{array}{l}\text { Maior diversidade do } \\
\text { uso do solo e } \\
\text { intensidade de } \\
\text { ocupação }\end{array}$ & Z4 e Z5 - Uso misto & $\begin{array}{l}\text { ZCPa e ZCPb - Zona } \\
\text { de Centralidade } \\
\text { Polar a e b } \\
\text { ZM3 - Zona Mista de } \\
\text { Alta Densidade }\end{array}$ & $\begin{array}{l}\text { ZEU - Zona Eixo de } \\
\text { Estruturação e } \\
\text { Transformação Urbana } \\
\text { ZEM - Zona Eixo de } \\
\text { Estruturação e } \\
\text { Transformação } \\
\text { Metropolitana }\end{array}$ \\
\hline $\begin{array}{l}\text { Média diversidade de } \\
\text { uso do solo e } \\
\text { intensidade de } \\
\text { ocupação }\end{array}$ & $\begin{array}{l}\text { Z2 e Z3 - Zona } \\
\text { Predominantemente } \\
\text { Residencial }\end{array}$ & $\begin{array}{l}\text { ZM2 - Zona Mista de } \\
\text { Média Densidade } \\
\text { ZM1 - Zona Mista de } \\
\text { Baixa Densidade }\end{array}$ & ZM - Zona Mista \\
\hline $\begin{array}{l}\text { Baixa diversidade do } \\
\text { uso e intensidade de } \\
\text { ocupação }\end{array}$ & $\begin{array}{l}\text { Z1 - Uso Estritamente } \\
\text { Residencial }\end{array}$ & \multicolumn{2}{|c|}{ ZER - Zona Exclusivamente Residencial } \\
\hline
\end{tabular}

Fonte: elaborado pelos autores.

\section{A estrutura urbana dos planos e propostas para São Paulo entre 1968 e 2016}

Os anos 1960 marcaram um momento de inflexão no planejamento urbano brasileiro, considerando as mudanças de postura e, essencialmente, da escala das intervenções. 0 processo de urbanização se intensificou para o que Reis (1996) chamou de "metropolização", como um fenômeno específico deste processo, com a expansão da industrialização no pós-guerra e as mudanças da estrutura produtiva, 
concentrada nas maiores cidades, que tiveram como corolário a ampliação do chamado "exército industrial de reserva" e o aprofundamento das crises urbana, habitacional e de transportes. Mas o agravamento dos problemas urbanos já vinha se intensificando nos anos anteriores. Não à toa, os primórdios do que viria a se chamar de reforma urbana no Brasil já estavam sendo engendrados ainda no governo Vargas, a considerar que a habitação nunca foi um problema totalmente enfrentado, sempre associado ao problema da terra. O Seminário de Habitação e Reforma Urbana de 1963 representou uma tentativa de incorporar a questão urbana nas reformas de base desenvolvidas no governo de João Goulart. Os arquitetos e urbanistas vinculados ao Partido Comunista Brasileiro tiveram uma contribuição decisiva neste sentido ao postular, ainda nos anos 1950, propostas para a democratização do acesso à terra, o embrião da luta que se intensificaria anos depois (Bonduki, 2018).

Embora a ditadura militar que se instalou em 1964 no Brasil tenha arrefecido qualquer possibilidade de reforma urbana na prática, os seus pressupostos continuaram presentes nas formulações que se sucederam, em organizações como o IBAM, reunindo profissionais engajados no tema, preparando-os para qualificar as políticas urbanas municipais (Junior, 2015), retomadas no período de redemocratização, nos anos 1980 que ressurgiram em um ambiente profícuo de planejamento que se estruturou ainda no governo militar a partir do SERFHAU (Serviço Federal de habitação e Urbanismo), de 1964 até 1975, e da PDUR (Política de Desenvolvimento Urbano e Regional), criada em 1976, no âmbito do II PND (Plano Nacional de Desenvolvimento). Lucchese \& Rossetto (2018) afirmam que, no período compreendido entre 1974 e o final da ditadura militar, a política urbana esteve mais comprometida com o território, lançando foco para as grandes cidades e regiões metropolitanas, abrangendo, além disso, o avanço gradual dos movimentos sociais urbanos.

Em São Paulo, é evidente que a implementação das políticas de desenvolvimento urbano através do BNH durante o regime autoritário esteve canalizada para o privilégio das classes sociais mais abastadas, cujos recursos foram canalizados para as regiões mais ricas do país - sul e sudeste (Souza, 2010). Ainda que a questão do transporte de massa tenha passado a ser definitivamente enfrentada, mesmo que a passos lentos, com a inauguração da primeira linha de metrô subterrâneo, em 1972, ela também se restringiu, neste primeiro momento, a um único vetor (norte - sul), e seria complementada, até a década de 1990, por outra linha na direção Leste-Oeste, que somadas, totalizavam 45 km de linhas (Deák, 2010). Por outro lado, os planos elaborados buscavam uma rápida ampliação do sistema. Mesmo sem receber força suficiente para tornar reais suas propostas, os planos elaborados desde 1968, a partir do PUB tiveram como premissa o enfrentamento dos deslocamentos populacionais na grande área metropolitana associados à organização do uso do solo, questão que continuou a ser permanentemente perseguida nestes anos. Na observação desta suposta continuidade, foi possível classificar os planos pesquisados em três períodos principais:

- Período 1 (1965 - 1985) - inserção das propostas de estrutura urbana do Plano Urbanístico Básico (PUB), de 1968 e do Plano Metropolitano de Desenvolvimento Integrado (PMDI), de 1970, além da Lei de Zoneamento de 1972, definidas principalmente por uma escala regional e um minucioso levantamento sobre os diversos aspectos sociais e econômicos. Este pensamento era aderente ao intuito de promover a centralização do poder de decisão das dinâmicas metropolitanas no município, correspondente ao período da ditadura militar.

- Período 2 (1985 - 2002) - abrange as propostas de planos diretores de 1982, 1985 e 1991. As propostas de 1985 e 1991 passaram a olhar mais de perto para as ocupações informais e irregulares no interior do tecido intraurbano. Foram introduzidos, de forma ainda gradativa, alguns instrumentos urbanísticos fundamentados nos princípios da reforma urbana, esboçados sob a ótica do período de redemocratização. Diante do avanço que propunham em um momento ainda de transição democrática, estes planos não foram aprovados e não se transformaram em leis. 
- Período 3 (2002 - 2016) - institucionalização dos princípios da reforma urbana, sob a égide do Estatuto da Cidade, aprovado em 2001. Abrange os planos diretores estratégicos de 2002 e de 2014, além das leis de parcelamento, uso e ocupação do solo de 2004 e 2016. Ao contrário do período anterior, todos estes documentos foram aprovados e instituídos como leis, dando maior alcance para a sua implementação. A efetiva busca de aplicação de instrumentos urbanísticos para dar cabo aos objetivos traçados, em especial através das parcerias público-privadas, foi a tônica deste período.

As principais propostas indicadas, no tocante à questão da estrutura urbana, e respectivos esquemas gráficos presentes nestes planos podem ser visualizadas no Quadro 3 e na Figura 5.

Quadro 3 - Os planos para São Paulo entre 1968 e 2014 e seus principais conteúdos

\begin{tabular}{|c|c|}
\hline Plano & Conteúdo principal \\
\hline $\begin{array}{l}\text { Plano Urbanístico Básico } \\
\text { (PUB) - } 1968\end{array}$ & $\begin{array}{l}\text { As recomendações do PUB (a médio prazo até } 1975 \text { e a longo prazo até 1991) para } \\
\text { a estrutura urbana consideravam orientar o crescimento até 1990, com uma visão } \\
\text { oposta aos planos antecedentes por duas razões principais: } 1 \text { - explicitar um maior } \\
\text { controle da expansão metropolitana e, } 2 \text { - priorizar o transporte coletivo para } \\
\text { promover maior mobilidade, necessária para atender à demanda das dinâmicas } \\
\text { urbanas consequentes da distribuição de emprego e moradia. Partindo de três } \\
\text { conceitos, quatro modelos e cinco alternativas, optou pelo modelo 3, vinculado ao } \\
\text { conceito } 4 \text { que postulava uma área central e uma polinucleação interligada por } \\
\text { um sistema de eixos estruturados para o transporte coletivo. }\end{array}$ \\
\hline $\begin{array}{l}\text { Plano Metropolitano de } \\
\text { Desenvolvimento Integrado } \\
\text { (PMDI) - } 1970\end{array}$ & $\begin{array}{l}\text { Apresentou dois conceitos. O primeiro apresentava um esquema similar ao do PUB, } \\
\text { tanto nas centralidades quanto na rede do sistema viário, e o segundo buscava } \\
\text { orientar a expansão urbana por meio de uma "descentralização concentrada", } \\
\text { partindo dos elementos naturais: os vales dos rios Tietê, Pinheiros e Tamanduateí, "três } \\
\text { rios, três vales, três corredores". Deste modo, o segundo conceito direcionava a } \\
\text { estrutura urbana por meio de instalação de corredores de alta densidade e } \\
\text { concentração de comércio e serviços nas sub-regiões, interligando as rodovias por } \\
\text { meio do anel rodoviário. }\end{array}$ \\
\hline $\begin{array}{l}\text { Plano Diretor de } \\
\text { Desenvolvimento Integrado }\end{array}$ & $\begin{array}{l}\text { O sistema de transporte projetado tinha como principais diretrizes: explorar ao } \\
\text { máximo a capacidade do sistema de transporte de massa existente, }\end{array}$ \\
\hline ॥ (PDDI II) - 1982 & $\begin{array}{l}\text { especialmente o modo ferroviário; aumentar a capacidade dos eixos principais de } \\
\text { transporte coletivo; melhorar interligação física e tarifária entre os diferentes modos } \\
\text { de transporte com terminais intermodais e ampliar e melhorar o sistema viário para } \\
\text { atender bairros periféricos. Indicava a necessidade de amenizar o caráter radio- } \\
\text { concêntrico da estrutura de transporte, permitindo ligações "inter-vetoriais". As } \\
\text { diretrizes para o uso e ocupação do solo tiveram como principais focos o } \\
\text { desenvolvimento de centros sub-regionais para estimular os adensamentos } \\
\text { populacionais ao seu entorno e a contenção da expansão horizontal nas áreas } \\
\text { periféricas, ainda que já assumisse os conflitos fundiários decorrentes da questão } \\
\text { inflacionária da habitação. }\end{array}$ \\
\hline
\end{tabular}

(continua) 
Quadro 3 - Os planos para São Paulo entre 1968 e 2014 e seus principais conteúdos

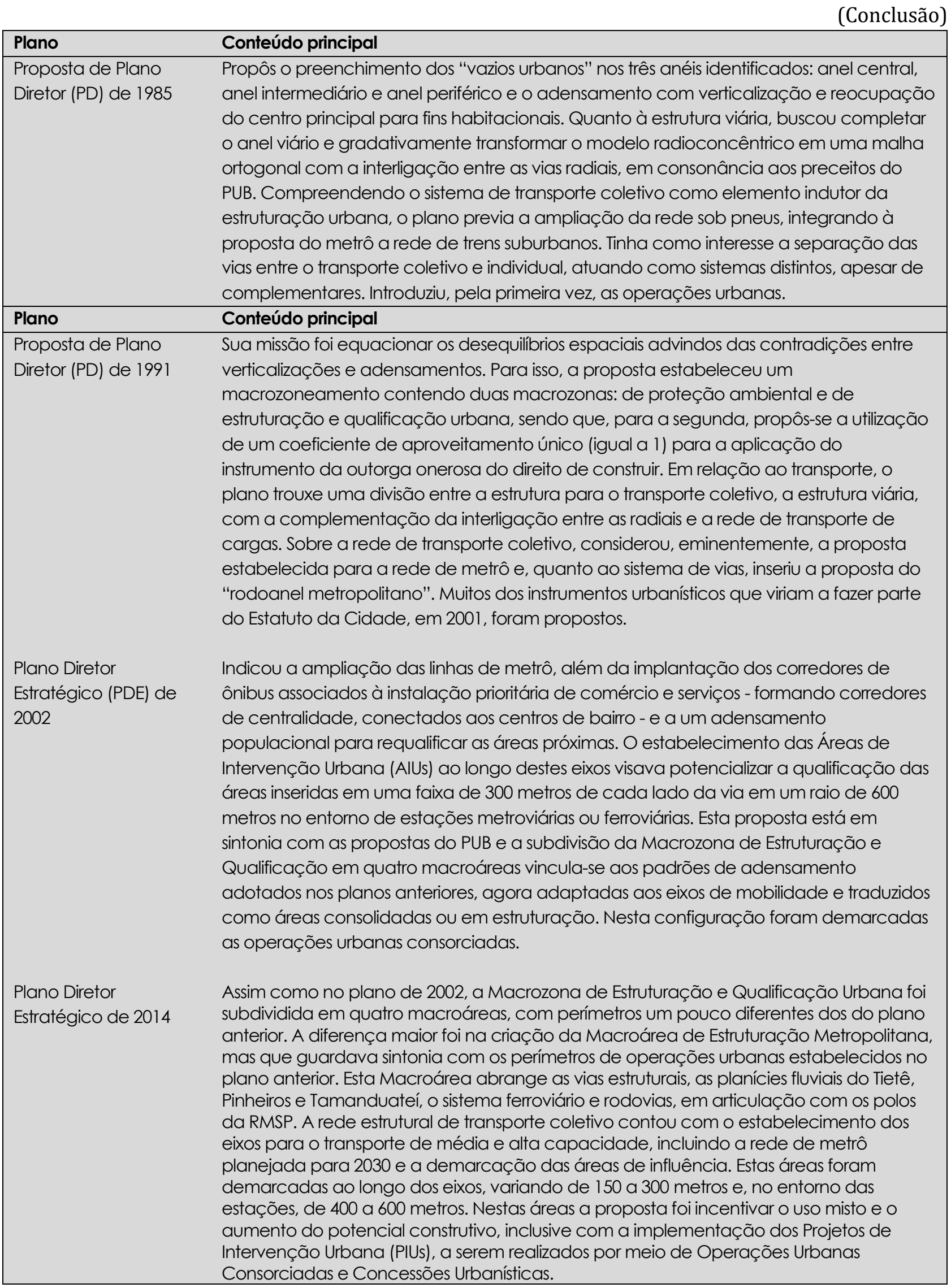

Fonte: elaborado pelos autores. 

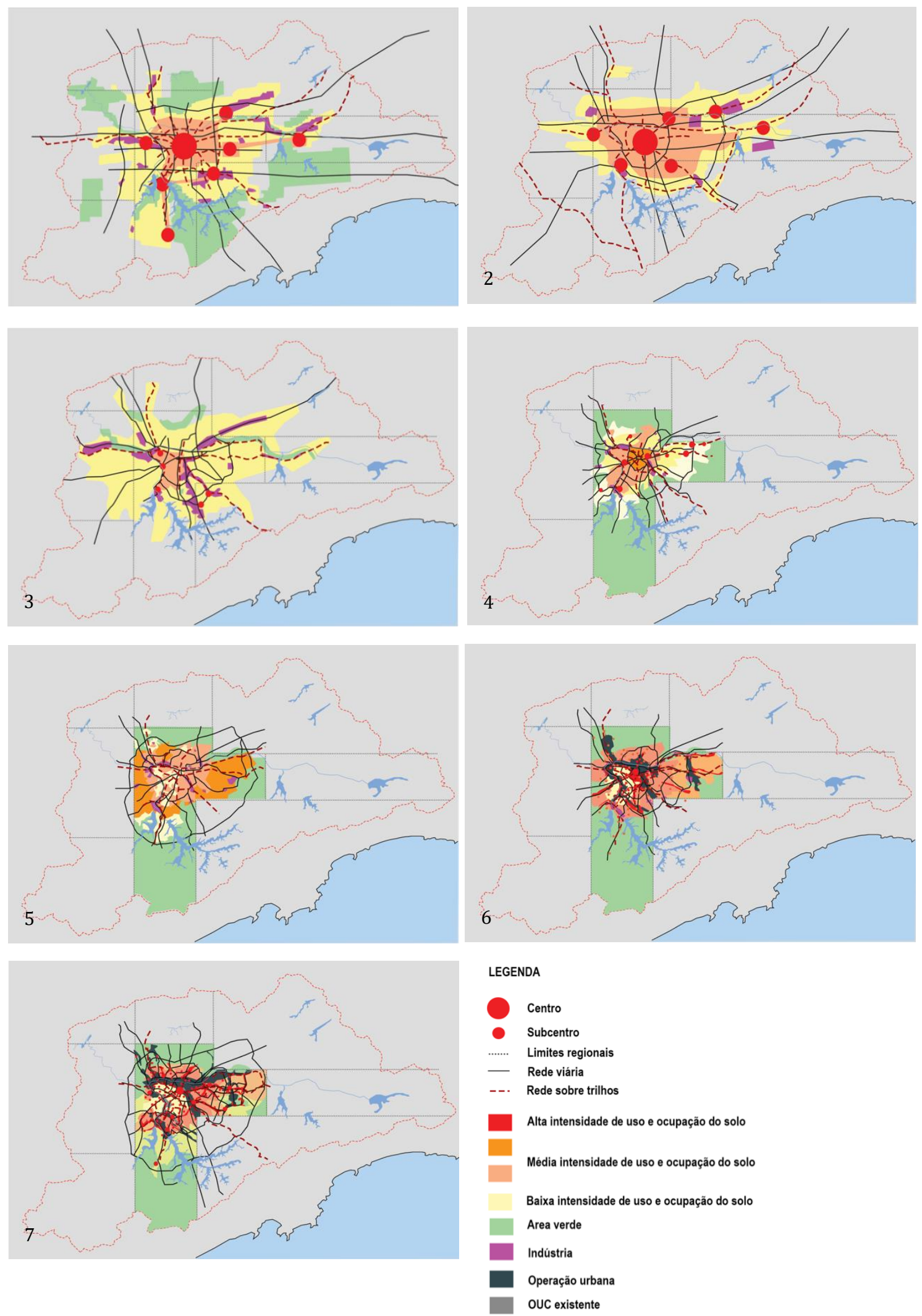

Figura 5 - Esquemas gráficos das propostas de estrutura urbana para São Paulo em seus respectivos planos (1968 - 2014). 1 - PUB (1968); 2 - PMDI (1971); 3 - PDDI II (1982); 4 - PD (1985); 5 - PD (1991); 6 - PDE (2002); 7 - PDE (2014). Fonte: elaborado pelos autores. 


\section{O pensamento sobre a estrutura urbana em São Paulo: uma discussão}

A forma inicial que estruturou a cidade de São Paulo, ainda nos primórdios de sua criação, definiu sua perene fisionomia. 0 seu desenvolvimento decorre de sua posição geográfica, como um nó regional que se propagou a partir de um sistema de caminhos que a ligavam com o litoral e o interior paulista (Langenbuch, 1968). Esta dinâmica definiu a sua estrutura radioconcêntrica, como comumente costuma ser reconhecida pelos estudiosos da sua forma. A expansão urbana que varreu a região metropolitana a partir da década de 1940 foi visivelmente marcada por esta estrutura, condicionando a ocupação urbana em todas as direções a partir de seus vetores radiais. A simples constatação de que o pensamento que se estabeleceu sobre a estrutura urbana no corpo de planos desenvolvidos foi, continuadamente, uma resposta direta à sua consolidação ao longo das décadas é decorrente desta dialética. Em um primeiro ensaio que busque dar uma resposta à hipótese, evidencia-se que, em praticamente todos os planos, assumiu-se a sua existência, postulando-se a partir dela um crescimento voltado a equilibrar as desigualdades e iniquidades territoriais, a conformação e a organização dos eixos de deslocamento, a junção e a articulação, sempre incompleta, com todo o complexo regional. A Figura 6 traz uma separação dos principais elementos traduzidos a partir da técnica da coremática, permitindo observar algumas características que demonstram esta continuidade.

Uma primeira observação diz respeito ao sistema de transporte de massa, um elemento essencial e que permaneceu como estruturador em todos os planos desenvolvidos, desde o PUB. Neste, a modelagem computacional deu origem à estimativa da capacidade de carga da rede sobre trilhos, que seguiu as linhas ferroviárias instaladas ainda no final do século XIX. A rede subterrânea do metrô vincular-se-ia à rede superficial formando um sistema, tendo suas linhas complementadas progressivamente, principalmente a partir do PDE de 2002 que passou a abrigar a primeira versão do PITU 2020 (Plano Integrado de Transporte Urbano) realizado pelo governo estadual. Do ponto de vista das ligações regionais, entretanto, desde o PUB, o sistema estrutural de transporte sobre trilhos permaneceu com um desenho semelhante, modificado apenas no PMDI, quando foram incorporados traçados em anéis ligando parte das lin has radiais em todo o quadrante sul da região. Já no PD de 1985, essa ideia foi abandonada, certamente por sua pouca viabilidade diante dos investimentos que se voltariam para potencializar a malha rodoviária. A insistente afirmação, entretanto, de que esta rede sobre trilhos deveria fazer parte do sistema estrutural de transportes definiu as ações desenvolvidas ao longo dos anos, em especial pelo governo estadual, ao adotar essa rede de trilhos como parte integrante do sistema de transporte (Metrô + CPTM), passando a se articular com mais consistência nos anos 2000, já na perspectiva de implantação do PITU 2020. 


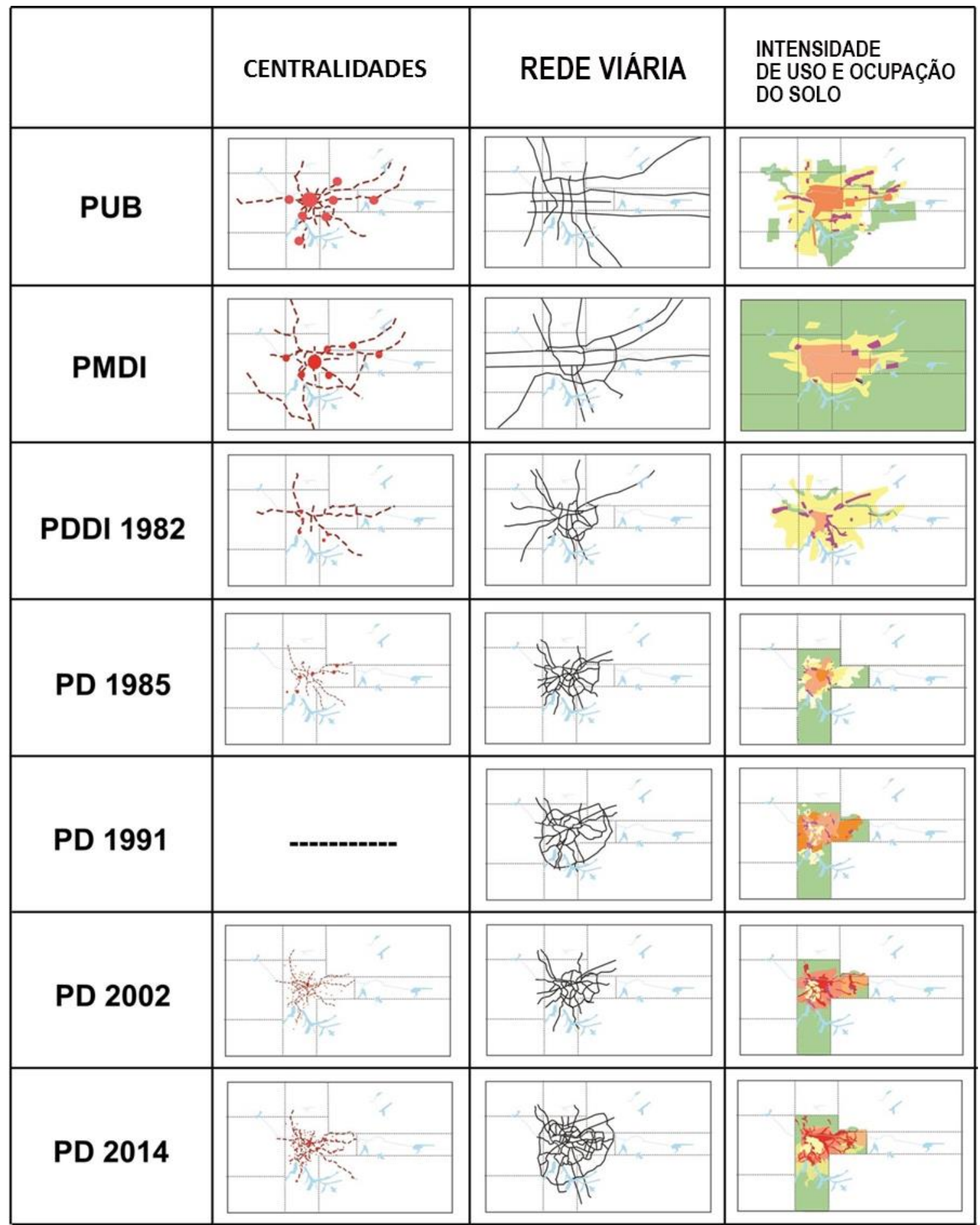

Figura 6 - Sistematização dos módulos elementares. Fonte: elaborado pelos autores.

Estabelecida uma mudança paradigmática no planejamento dos anos 1960, diante dos desafios colocados pelas dinâmicas regionais, o PUB introduziu um ideário que se afirmaria nos planos posteriores. Anelli (2007) afirma que o plano deixou vestígios nestes, como no PMDI e no PDDI. Mentone (2015) esclarece, cartograficamente, esses desdobramentos a partir da análise do PMDI e Feldman (2005) também destaca os vestígios da proposta da rede de transporte retomada, em certa medida, na lógica de demarcação das zonas periféricas na Lei de Zoneamento de 1972, ainda que refutando o princípio estruturador.

A rede viária estrutural também é um aspecto que merece ser observado. Aqui a questão dos eixos viários esteve vinculada, certamente, ao pensamento rodoviarista, mas se arrefece ao observá-la na 
perspectiva de se consolidar um sistema articulado de transporte de massa. Estaria implícito aí, por suposição, que o PUB procurou desvincular os dois sistemas, assumindo o de transporte de massa na estrutura radial e o viário, em uma estrutura em grelha, completamente estranha, portanto, à estrutura urbana que já existia, conforme é possível visualizar na Figura 6. 0 plano tentava contrapor a estrutura radial, justificando a importância de estabelecer ligações mais rápidas nos sentidos claramente determinados nas direções norte - sul / leste - oeste. Mas não foi suficiente para redefinir esta lógica. Paulatinamente a ideia foi sendo abandonada e já no PMDI é possível perceber que a própria estrutura em grelha deu lugar a um conjunto de vias em anéis. 0 sistema radial por sua vez foi acrescentado no PDDI de 1982, em uma clara determinação de que este sistema era o mais possível de se implementar. O grande anel viário (mais conhecido como rodoanel) já estava desenhado no planejamento da metrópole e foi incorporado pela primeira vez na proposta de 1991, retomado no plano de 2016, quando já estava praticamente todo implantado. A utilização destas vias no sistema radial para o transporte coletivo sob pneus foi algo que se perseguiu nas propostas, em especial a partir de 2002, sustentando a ideia de um sistema integrado de transporte de massa.

A estrutura pensada para estes eixos de transporte foi determinante para o posicionamento de um conjunto de centralidades, associadas, é evidente, a polos aglutinadores distribuídos ao longo destes eixos. As propostas, neste sentido, variaram, entre um plano e outro, mas estiveram presentes, enquanto ideia, em quase todos, conforme Figura 6. Até a proposta de 1985, que ainda buscava aplicar as referências do PUB, este conjunto de centralidades restringia-se a alguns polos. A partir de 2002, um conjunto de microcentralidades foi acrescentado, em sintonia com os eixos metro-rodoviários. No PUB, ter estas centralidades vinculadas ao sistema radial de transporte de massa (conceito 4) buscava enfatizar a necessidade de redistribuir os postos de trabalho para amenizar os movimentos pendulares entre o centro e as periferias. Em 2002, já sob o manto dos preceitos da reforma urbana, a introdução das subcentralidades associou-se efetivamente aos terminais e estações de Metrô onde foram propostas as AIUs (Áreas de Intervenção Urbanística) em um raio de 600 metros das estações metroviárias e ferroviárias, ideia novamente incluída no plano de 2014. Implícito à motivação de potencializar o uso e ocupação do solo nestes pontos, desde o PUB de 1968 buscava-se, assim como neste, induzir uma dinâmica descentralizadora, em rede, para uma melhor distribuição das atividades e uma diminuição das pendularidades, ainda que em pontos e escalas diversos.

A vinculação deste sistema de mobilidade metropolitana com o uso e ocupação do solo reitera um posicionamento que também é transversal aos planos, em acordo ao conceito da intensificação do adensamento nos corredores de transporte coletivo, como adotado em Curitiba no plano preliminar de urbanismo, de 1965 (Gnoato, 2006). No PUB, esta relação é clara e ficaria ainda mais explícita na proposta de zoneamento a ele anexada, ainda que, neste caso, esta intensificação estivesse vinculada eminentemente à proposta de eixos viários ortogonais e não ao sistema de transporte radial e mais direcionada ao uso do solo e menos à ocupação. O PDDI de 1982 reforçou esta vinculação, mais restrita, entretanto, aos usos industriais, onde as fábricas já estavam instaladas ao longo de eixos ferroviários. É certo que, neste caso, houve uma ruptura da proposta inicial do PUB nos planos das décadas de 1980 e 1990, já que esta vinculação explícita foi abandonada, só retomada nos documentos de 2002 e 2014, sendo que, neste último, teve um caráter estruturante, condicionado, especialmente pela implantação de corredores exclusivos de ônibus já nos primeiros anos da década de 2000 e as várias linhas de metrô, cujo sistema foi se ampliando também a partir do início desta década. Neste sentido, o plano de 2014 se reencontra com o PUB. Não coincidentemente os discursos se retomam: os três rios, três vales e três corredores do PMDI e os três rios e sistemas rodoferroviários, no PDE de 2014. A quarta coluna da Figura 6 demonstra como, a partir de 2002, a relação entre a proposta de diversificação e adensamento do uso e ocupação do solo ganhou força, retomando, na escala municipal, o que o PUB propôs para a escala metropolitana. 
Já a concepção acerca dos padrões de uso e ocupação para o complexo tecido urbano e regional foi menos contínua, embora seja pertinente afirmar que, à exceção da variação observada nos tamanhos das manchas relacionados com os padrões de adensamento e intensificação do uso do solo, houve, em certa medida, a permanência de uma relação estrutural entre centro e periferia, sendo o centro e centro expandido áreas propícias ao adensamento e à maior variação do uso do solo e as periferias, à manutenção de médias / baixas densidades e menor intensificação do uso do solo, padrão quebrado apenas pela rígida permanência das áreas exclusivamente residenciais de baixa densidade no vetor sudoeste. A partir de 2002, essa proposta foi sendo traduzida em termos conceituais quanto aos padrões de consolidação nas propostas de macroáreas: consolidada, em qualificação, etc. Em 2014, a pretensão em se definir uma área de caráter metropolitano, chamada de Arco do Tietê, reverberou em uma proposta que também se associava à ideia de criar novas centralidades, agora com o intuito de se aproveitar os imóveis ociosos advindos da obsolescência industrial ao longo dos eixos ferroviários. Curiosamente, apenas a proposta de 1991 inverte este modelo ao assumir que às periferias deveriam ser destinadas mais terras para o adensamento populacional e à região central, manutenção das densidades que já estavam presentes, proposta coerente com o modelo conceitual do solo criado que imputava para esta região o índice de aproveitamento básico igual a 1.

A verificação de todo este ideário com aquilo que em parte se adotou a partir dos instrumentos autoaplicáveis, como a lei de zoneamento e de uso e ocupação do solo (Figura 7), possibilita compreender a abertura para a resistência à implementação das propostas concebidas desde os anos 1960, em São Paulo por parte de grupos sociais com interesses específicos - proprietários e empreendedores imobiliários - que se distinguem das propostas dos planos, tendo em vista principalmente que o zoneamento, em São Paulo, foi pensado desde cedo como um instrumento de proteção à propriedade privada, conforme apontou Feldman (2005). Ao comparar a proposta de zoneamento traçada pelo PUB e a aprovada em 1972, percebe-se o abandono irrestrito da combinação entre os eixos viários e de transporte e a intensificação do uso do solo, conforme podemos comparar entre os esquemas 1 e 2 da Figura 7. Como já havia apontado Feldman (2005), o zoneamento se deslocou de uma proposta de planejamento que já vinha sendo realizada em São Paulo, distorcendo, em termos práticos, uma concepção que se fazia presente no ideário do urbanismo. A pulverização de zonas como polígonos isolados não teve outra razão senão proteger os interesses da produção do solo para o mercado. Entretanto, as leis de 2004 e 2016, inseridas na nova proposta de planejamento dos seus respectivos planos, passaram a vincular, como na premissa dos planos dos anos 1960, a articulação entre adensamento, usos mistos e corredores / eixos estruturantes de transporte. A lei de parcelamento, uso e ocupação de 2016 exacerbou esta acepção, embora mantendo ainda uma estrutura zonal fragmentada e complexa. 

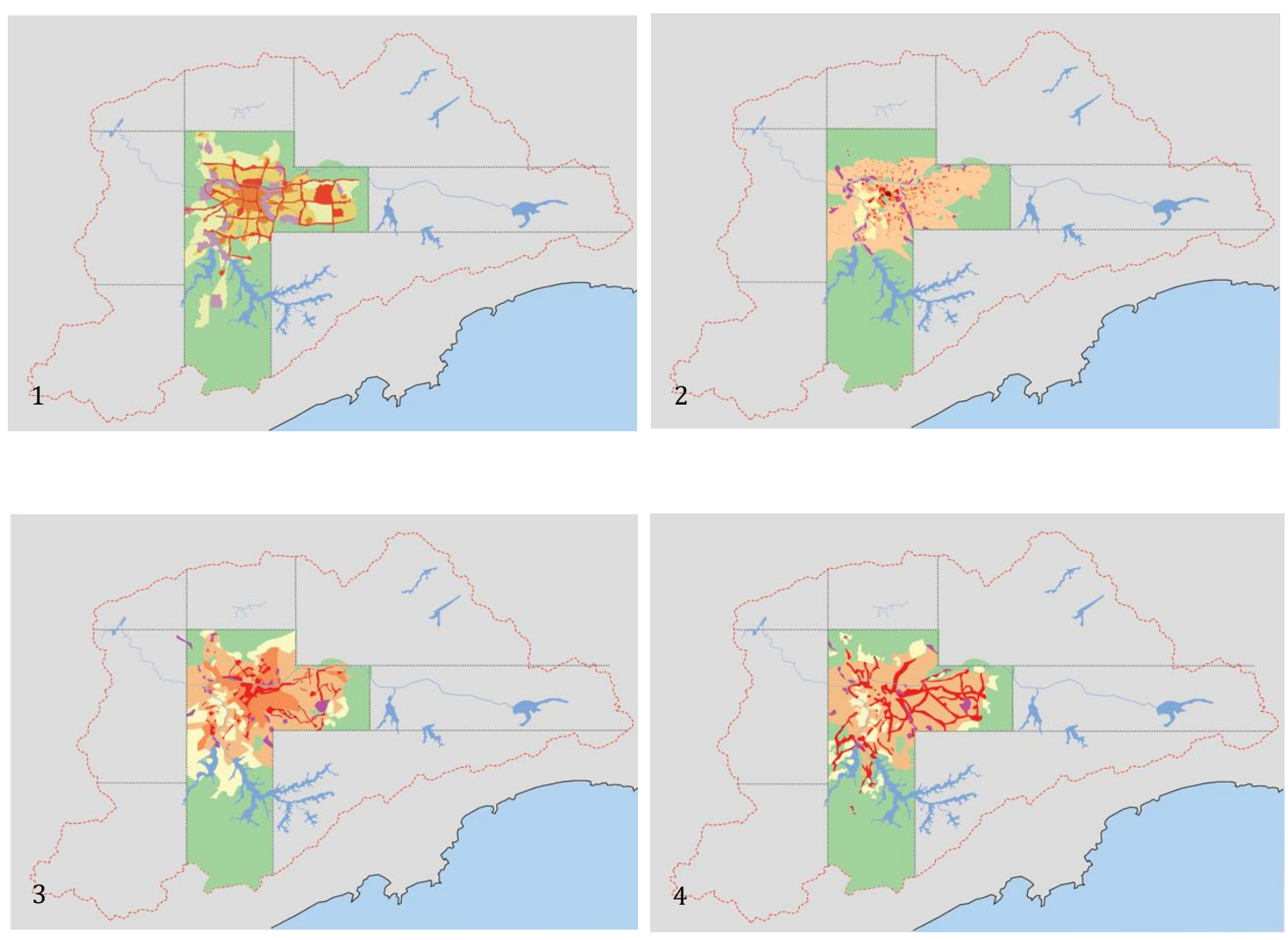

Figura 7 - Esquemas gráficos das propostas de estrutura urbana para São Paulo nas propostas de leis de zoneamento e de Uso, parcelamento e ocupação do solo (1968 - 2016). 1 - Proposta de zoneamento vinculada ao PUB/68; 2 - Lei de zoneamento de 1972; 3 - LUOPS de 2004; 4 - LUOPS de 2016. Fonte: elaborado pelos autores.

\section{Considerações finais}

A adoção do método semiológico para uma compreensão mais precisa das propostas de estrutura urbana presentes nos vários planos para São Paulo a partir do final dos anos 1960 elevou o grau de percepção sobre a importância desta questão nos planos urbanísticos, em especial, em escalas metropolitanas. Sabe-se bem quão decisivo pode ser um modelo de estrutura urbana para o destino de uma metrópole, com especial atenção para a qualidade de vida dos seus habitantes diante do enorme desafio de se viver e trabalhar a grandes distâncias. A clareza de um projeto de estrutura urbana no âmbito de um plano ou proposta de intervenção urbana passa, assim, por um entendimento dos desafios presentes na estrutura que já vem se consolidando ao longo dos anos.

No caso investigado, foi possível perceber que, em termos conceituais, muitas das proposições permaneceram nos planos, sendo perseguidas a cada versão desenvolvida. Assim se pode dizer do sistema estrutural de transporte seguindo o modelo radial, da fixação de subcentralidades, sempre associadas a uma tentativa de intensificar atividades e amenizar as pendularidades e da associação entre intensificação do uso e ocupação do solo e eixos viários / transporte de massa. Em menor medida, a organização do uso e ocupação do solo pelo território teve uma continuidade em termos conceituais, mas a partir de arranjos diferentes já que variou tanto na abrangência das áreas de maior intensidade de uso e ocupação do solo como na própria intensidade, que foi se acentuando, para determinadas regiões nos planos mais atuais. Talvez esta tenha sido a questão mais sensível às alterações da estrutura urbana condicionadas pelo valor do solo e sua interferência nas pressões pelo adensamento construtivo. Em termos gerais, entretanto, o único plano que divergiu em vários aspectos dos demais foi o de 1991, já que se voltou com mais intencionalidade para a implementação dos preceitos da reforma urbana, no 
contexto da nova Constituição que acabava de ser promulgada. Adotou uma lógica de maior equalização espacial, de forma a evitar a indução dos padrões de adensamento nos desequilíbrios socioespaciais da estrutura urbana dicotômica entre centro e periferia. Não à toa, foi um dos primeiros planos a observar os tecidos existentes nas áreas consolidadas e diferenciá-los em termos de padrão socioeconômico (favelas e loteamentos irregulares).

A lei de zoneamento de 1972 e sua vigência até 2004, quando uma nova a substituiu, mostra a força de alguns setores sociais que resistiram firmemente às concepções traçadas pelas propostas desenvolvidas desde o PUB. Nenhuma destas propostas vingou em termos institucionais, ora pouco lembradas, ora fora do alcance legislativo. Assim é que, por qualquer que seja a razão pela qual este modelo prevaleceu, foi o que deu o tom na consolidação da estrutura urbana da metrópole. Mas concepções ali traçadas nos anos 1960 voltariam com força nos planos dos anos 2000, demonstrando, neste sentido, a permanência de um pensamento que, desta vez, se implementaria por completo com a aprovação legislativa tanto dos planos como dos seus respectivos instrumentos de zoneamento. Além disso, cabe destacar que a atuação da esfera estadual neste contexto durante as décadas que se seguiram ao PUB foi decisiva para que alguns aspectos traçados, desde o plano, continuassem a ser perseguidos. Esta relação entre estado e município, em especial em áreas metropolitanas, deve ser um aspecto a ser analisado, mesmo com a inexistência de entidades políticas metropolitanas que executem o planejamento nesta escala. Houve uma progressiva tentativa de realizar este pensamento, seja no âmbito estadual, seja no municipal, o que sinaliza, bem ou mal, a permanência do ideário que foi permeando as ações desenvolvidas - assim é a integração entre a rede de metrô com a rede ferroviária da CPTM, a adoção dos corredores exclusivos para transporte coletivo, a própria ampliação gradual da rede de metrô, embora em ritmo mais lento do que o planejado.

\section{Referências}

Anelli, R. L. S. (2007). Redes de mobilidade e urbanismo em São Paulo: das radiais/perimetrais do Plano de Avenidas à malha direcional PUB. Arquitextos, (82.00).

Archela, R. S. (2001). Contribuições da semiologia gráfica para a cartografia brasileira. Revista Geografia, 10(1), 45-50.

Bonduki, N. (2018). Do governo Vargas ao Seminário de Habitação e Reforma Urbana: as tentativas pioneiras de enfrentar a questão urbana. In N. Bonduki (org.), A luta pela Reforma Urbana no Brasil. Do Seminário de Habitação e Reforma Urbana ao Plano Diretor de São Paulo. (1a ed., p. 15-34). São Paulo: Instituto da Casa da Cidade.

Brasil (1988, 5 de outubro). Constituição da República Federativa do Brasil. Brasília: Diário Oficial da União, Seção 1.

Brasil (2001, 10 de julho). Lei 10.257, de 10 de julho de 2001. Regulamenta os artigos 182 e 183 da Constituição Federal, estabelece diretrizes gerais da política urbana e dá outras providências. Brasília: Diário Oficial da União, Seção 1.

Brasil (2015, 12 de janeiro). Lei 13.089, de 12 de janeiro de 2015. Institui o Estatuto da Metrópole, altera a Lei $n^{\circ}$ 10.257, de 10 de julho de 2001, e dá outras providências. Brasília, Diário Oficial da União, Seção 1.

Brunet, R. (1986). La carte-modèle et les chorèmes. Mappemonde, 4, 2-6.

Campos Filho, C. M., \& Somekh, N. (2002). A cidade que não pode parar: Planos urbanísticos de São Paulo no século XX. São Paulo: Editora Mackenzie.

Cerasoli, J. F. (2014). A formação do campo conceitual de estudos sobre a cidade: (im)possibilidades de uma abordagem biográfica. In R. Faria, J. Cerasoli, \& F. Lira (org.), Urbanistas e urbanismo no Brasil. Entre trajetórias e biografias. São Paulo: Alameda.

Deák, C. (2010). Elementos de uma política de transportes para São Paulo. In C. Deák, \& S. R. Schiffer (org.), O processo de urbanização no Brasil. São Paulo: Edusp.

Feldman, S. (2005). Planejamento e zoneamento - São Paulo 1947 - 1972. São Paulo: EDUSP.

Friedmann, J. (2011). Insurgencies: Essays in planning theory. Abingdon: Routledge. 
Gnoato, S. (2006). Curitiba, cidade do amanhã: 40 depois. Algumas premissas teóricas do Plano Wilheim-IPPUC. Arquitextos, São Paulo, (72.01).

Gonçalves, A. de F. (2012). Avaliação de território e coremática. Aplicação ao município de São Paulo (Tese de Doutorado). Universidade de São Paulo, São Paulo.

Junior, L. R. C. S. (2015). Municipalismo e ditadura militar: O Instituto Brasileiro de Administração Municipal e a difusão de políticas urbanas. In Anais ENANPUR. Belo Horizonte: ANPUR.

Kneib, E. C. (2014). Subcentros urbanos: contribuição conceitual e metodológica à sua definição e identificação para planejamento de transportes (Tese de doutorado). Departamento de Engenharia Civil e Ambiental, Faculdade de Tecnologia, Universidade de Brasília, Brasília.

Langenbuch, J. R. (1968). A estruturação da Grande São Paulo: estudo de geografia urbana. (Tese de Doutorado). Faculdade de Filosofia, Ciências e Letras de Rio Claro, Universidade Estadual de Campinas, Campinas.

Leme, M. C. da S. (1999). Urbanismo no Brasil. São Paulo: Edusp.

Lucchese, M. C., \& Rossetto, R. (2018). A política urbana no governo militar (1964 - 1985). In N. Bonduki (org.), A luta pela Reforma Urbana no Brasil. Do Seminário de Habitação e Reforma Urbana ao Plano Diretor de São Paulo (1a ed., p. 3580). São Paulo: Instituto da Casa da Cidade.

Mentone, R. L. (2015). Plano metropolitano de desenvolvimento integrado da Grande São Paulo/PMDI-GSP, 1970: da expectativa ao desconhecimento (Dissertação de Mestrado). Faculdade de Arquitetura e Urbanismo, Universidade de São Paulo, São Paulo.

Meyer, R., Grostein, M. D., \& Biderman, C. et al. (2004). São Paulo metrópole. São Paulo: EDUSP, Imprensa Oficial.

Reis, N. G. (1996). Notas sobre a organização da Regiões Metropolitanas. Cadernos de Pesquisa do LAP, 12.

Rodrigue, J.-P. (2016). Transportation and urban form. The Geography of Transports Sistems. Taylor \& Francis.

São Paulo (Estado) (1970). Secretaria de Economia e Planejamento. Plano Metropolitano de Desenvolvimento Integrado: Seminário de Planejamento Metropolitano. São Paulo: GEGRAN - Grupo Executivo da Grande São Paulo.

São Paulo (Estado) (1982). Secretaria de Estado dos Negócios Metropolitanos / Empresa Metropolitana de Planejamento da Grande São Paulo. Plano Metropolitano de Desenvolvimento Integrado da Grande São Paulo: bacia do Guarapiranga. São Paulo: EMPLASA.

São Paulo (Município) (1968). Plano Urbanístico Básico - PUB, Consórcio ASPLAN, Daly Montreal, Wilbur Smith, São Paulo. São Paulo: Grupo Executivo de Planejamento/Secretaria de Obras/ PMSP.

São Paulo (Município) (1971, 30 de dezembro). Lei n. 7.688, de 30 de dezembro de 1970. Dispõe sobre a instituição do Plano Diretor de Desenvolvimento Integrado do município de São Paulo - PDDI - SP, e dá outras providências. São Paulo: Diário Oficial do Município de São Paulo.

São Paulo (Município). (1972, 1ํ de novembro). Lei n. 7.805, de 1ํo de novembro de 1972: Dispõe sobre o parcelamento, uso e ocupação do solo do Município e dá outras providências. São Paulo: Diário Oficial do Município de São Paulo.

São Paulo (Município) (1982). Plano Diretor de desenvolvimento integrado do município de São Paulo-PDDI-II: objetivos e diretrizes gerais. São Paulo: Secretaria Municipal de Planejamento.

São Paulo (Município) (1985). Plano diretor do Município de São Paulo, 1985/2000. São Paulo: Secretaria Municipal de Planejamento.

São Paulo (Município) (1991). Projeto de Lei do Plano Diretor do Município de São Paulo. São Paulo: Diário Oficial do Município, suplemento.

São Paulo (Município). (2002). Lei no 13.430, de 13 de setembro de 2002: institui o Plano Diretor Estratégico e o Sistema de Planejamento e Gestão do Desenvolvimento Urbano do Município de São Paulo. São Paulo: Diário Oficial do Município.

São Paulo (Município). (2004). Lei no 13.885 de 25, de agosto de 2004: disciplina o parcelamento, uso e a ocupação do solo no Município de São Paulo, de acordo com a Lei no⒔430, de 13 de setembro de 2002 - Plano Diretor Estratégico. São Paulo: Diário Oficial do Município.

São Paulo (Município). (2014). Lei no 16.050, de 31 de julho de 2014: aprova a política de Desenvolvimento Urbano e o Plano Diretor Estratégico do Município de São Paulo e revoga a Lei no 13.430/2002. São Paulo: Diário Oficial do Município. 
São Paulo (Município). (2016). Lei no 16.402 de 22, de março de 2016: disciplina o parcelamento, uso e a ocupação do solo no Município de São Paulo, de acordo com a Lei nº16.050, de 31 de julho de 2014 - Plano Diretor Estratégico. São Paulo: Diário Oficial do Município.

Silva, É. T. da. (2013). Estrutura urbana e mobilidade espacial nas metrópoles. Rio de Janeiro: Letra Capital.

Souza, M. A. de. (2010). O II PND e a política urbana brasileira. Uma contradição evidente. In Deák, C. \& Schiffer, S. R. (org.), O processo de urbanização no Brasil. São Paulo: Edusp.

Théry, H. (2012). Modelos gráficos da competitividade paulistana. In Torres-Freire, C., Wissenbach, K. Metamorfoses paulistanas: atlas geoeconômico da cidade. São Paulo: Cebrap/SMDU/Imprensa Oficial/Editora Unesp, 178-186.

Villaça, F. (2017). Espaço Intraurbano no Brasil (2a ed.). São Paulo: Studio Nobel / FAPESP / Lincoln Institute.

Editor responsável: Rodrigo Firmino

Recebido em 25 mai. 2020

Aprovado em 16 set. 2020 